\title{
PROTEIN AND SENSORY QUALITY OF A FOOD SUPPLEMENT FORMULATED FOR THE ELDERLY
}

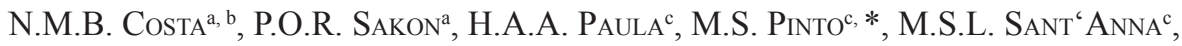 \\ T.F. ARAÚJo ${ }^{c}$ and V.P.R. Minim ${ }^{\mathrm{c}}$ \\ ${ }^{a}$ Department of Nutrition and Health, Federal University of Viçosa,Viçosa-MG. Brazil \\ ${ }^{\mathrm{b}}$ Currently teacher at the Federal University of Espirito Santo, Alegre-ES. Brazil \\ ${ }^{\mathrm{c}}$ Department of Food Science and Technology, Federal University of Viçosa, Viçosa-MG. Brazil
}

(Received: 17 July 2012; accepted: 4 January 2013)

\begin{abstract}
This study aimed to evaluate the composition, the protein quality, and the acceptability of a powder dietary supplement formulated for elderly people. The centesimal composition was analysed according to A.O.A.C. methods and the protein quality was assessed in weaning rats, by comparing Protein Efficiency Ratio (PER), Net Protein Ratio (NPR), and True Digestibility (TD) of the supplement with a casein-control based on AIN-93G diet. For the acceptance test samples of four flavours of the supplement dissolved in whole milk were offered to each judge, in monadic form. To assess the overall acceptability a scale of seven points was used. The sensory panel was composed of 121 Brazilian panellists, with mean age of $68.28 \pm 5.78$ years. The supplement is promising in reaching the nutritional demands of the elderly, providing high content of protein and fibre and low content of fat. The values found for PER and NPR were shown to be superior to the control group of casein $(\mathrm{P}<0.05)$ and the digestibility was higher than $90 \%$, showing that the supplement presented characteristics of a high nutritional value protein source. The supplements with banana, vanilla, and strawberry flavour were the most accepted and did not differ significantly for the overall acceptability.
\end{abstract}

Keywords: food supplements, elderly, nutritional quality, sensory acceptance

Increased life expectancy is an obvious fact in the world. In developing countries there has been a process of aging more pronounced than that observed in developed countries. In Brazil, the aging process can be exemplified by the ratio of people aged 60 or older in the total population increasing from $4.1 \%$ in 1940 to $8.6 \%$ in 2000 . This fact calls attention to the greater need to deepen the understanding of the role of nutrition as an important factor in the aging process (LIMA-COSTA \& CAMARERO, 2008). In this context, the most important nutritional disorder observed in the elderly is the protein-energy malnutrition, which is associated with increased mortality, susceptibility to infections, and reduced quality of life. However, the protein-energy malnutrition is often ignored because it is seen, mistakenly, as part of the normal process of aging (Otero et al., 2001; Lima-Costa \& CAMARERO, 2008).

The National Health Surveillance Agency (ANVISA) defines a food supplement, also known as nutritional supplement, as "a product produced in order to supplement the daily diet of a healthy person, who want to compensate a possible deficit of nutrients, in order to achieve the recommended daily intake (RDI)" (BRAZIL Ministério DA SAÚde, 1998). As the elderly people constitute a risk group for malnutrition, it is necessary to strictly meet the dietary requirements (MENEZES \& MARUCCI, 2005).

The development of new products highlights the need of applying tests that give safe, effective, and representative consumer's opinion (TREPTOW et al., 1998).

\footnotetext{
* To whom correspondence should be addressed.

Phone: +55 (31) 3899-3817, fax: +55 (31) 3899-2208; e-mail: mimenorddd@yahoo.com.br
} 
Given the above explanation, the aim of this study was to analyse the nutritional and sensory characteristics of a food supplement specifically formulated for senior citizens through determining the centesimal composition, protein quality assessment, and acceptance of four different flavours.

\section{Materials and methods}

In this experiment, a dietary supplement formulated for elderly people was used, developed by a technology company of the Federal University of Viçosa, Minas Gerais. The product was made from milk powder, whey protein, albumin, collagen, inulin, polydextrose, maltodextrin, fructose, sodium saccharin, minerals, and vitamins. The composition of vitamins and minerals was established according to the nutritional recommendations for elderly males (I.O.M., 1997, 1998, 2000, 2001). The mix of minerals and vitamins in a portion of $30 \mathrm{~g}$ of supplement provided $30 \%$ of the RDI, meeting the requirement of the Ordinance of ANVISA, calling for a minimum of $25 \%$ of the RDI (BRAZil Ministério da SaÚde, 1998).

\subsection{Proximate composition}

For determination of moisture, total lipid, total protein, dietary fibres (total, soluble, and insoluble), and ash content we followed the recommendation of A.O.A.C. (2002). The carbohydrate content was determined by percentage difference between the levels of proteins, lipids, moisture, ash, and fibre.

\subsection{Biological assay}

1.2.1. Experimental design. The bioassay was composed of 18 male Wistar rats (Rattus novergicus, variety albinos, Rodentia). They came from the Central Animal Housing Laboratory, Federal University of Viçosa. The weaning rats were 23 days old, weighted $75.8 \pm 4.4 \mathrm{~g}$. A randomized block design with 6 replications has been used.

The experiment consisted of three groups: nitrogen-free diet (NF); casein diet (CAS), which was the control group; and a test diet (SA), which contained the food supplement for the elderly as the protein source. The composition is presented in Table 1 . The rats were distributed among the groups in a systematic way to enable the least possible variation within and between groups. They were kept in individual cages where they received food ad libitum and deionized water for 14 days, with light cycle of 12 hours and constant temperature of $23 \pm 2{ }^{\circ} \mathrm{C}$.

1.2.2. Digestibility. For the determination of digestibility, diets were stained with indigo carmine, with the proportion of $100 \mathrm{mg}$ per $100 \mathrm{~g}$ diet, and offered to animals at day $7 \mathrm{up}$ to day 10 of the experiment. Faeces were collected between days 8 and 11, dried in a stove with air circulation at $105^{\circ} \mathrm{C}$ for $24 \mathrm{~h}$, and the faecal nitrogen was determined by the semi-micro Kjeldahl method (A.O.A.C., 2002).

True digestibility (TD) was determined as follows:

$$
\mathrm{TD}=\mathrm{I}-(\mathrm{F}-\mathrm{Fk}) \times 100 / \mathrm{I}
$$

where I is nitrogen intake by the test group, $\mathrm{F}$ is the faecal nitrogen of the test group, and Fk is the faecal nitrogen of the nitrogen-free group. 
Table 1. Composition and protein content of experimental diets used in the biological assay for evaluating the protein quality of the food supplement

\begin{tabular}{lccc}
\hline \multirow{2}{*}{ Ingredients } & \multicolumn{3}{c}{ Diets $(\mathrm{g} / 100 \mathrm{~g})$} \\
\cline { 2 - 4 } & 0.00 & $\mathrm{CAS}$ & $\mathrm{SA}$ \\
\hline Casein & 0.00 & 12.10 & 0.00 \\
Dietary supplement & 13.20 & 0.00 & 24.88 \\
Maltodextrin & 10.00 & 13.20 & 13.20 \\
Sucrose & 7.00 & 7.00 & 10.00 \\
Soybean oil & 5.00 & 5.00 & 7.00 \\
Microfine cellulose & 3.50 & 3.50 & 5.00 \\
Mineral mix & 1.00 & 1.00 & 3.50 \\
Vitamin mixture & 0.30 & 0.30 & 1.00 \\
L-cystine & 0.25 & 0.25 & 0.30 \\
Choline bitartrate & 59.75 & 47.64 & 0.25 \\
Cornstarch & - & 9.50 & 34.86 \\
Protein & & & 9.88
\end{tabular}

Diets: LN: nitrogen-free diet; CAS: control diet of casein; SA: test diet containing the dietary supplement

1.2.3. Food Efficiency Ratio (FER), Protein Efficiency Ratio (PER), and Net Protein Ratio (NPR). The PER was determined on day 14 of the experiment, considering the weight gain in relation to the animal protein intake (A.O.A.C., 2002) as follows:

$\mathrm{PER}=$ weight gain of test group $(\mathrm{g})$ /protein consumed by test group $(\mathrm{g})$.

The FER was also determined on the $14^{\text {th }}$ day of the experiment and is defined as:

FER=weight gain of test group $(\mathrm{g}) \times 100$ /intake of the test group $(\mathrm{g})$.

NPR was determined taking into account the weight gain of the test group, plus weight loss of nitrogen-free group (endogenous), according to BeNDER and Doell (1957):

$\mathrm{NPR}=$ weight gain of test group $(\mathrm{g})+$ weight loss of nitrogen-free group $(\mathrm{g}) /$ protein consumed by test group $(\mathrm{g})$.

The values obtained can be expressed as a percentage relative to the value obtained for the casein diet which is considered $100 \%$. This percentage is called relative PER (RPER) and relative NPR (RNPR).

\subsection{Preparation of samples for acceptance testing}

1.3.1. Sensory analysis. Four different flavours of the food supplement formulated for elderly people were used: banana, vanilla, chocolate, and strawberry. The beverage was prepared following the preparation instructions: $30 \mathrm{~g}$ of supplement powder in $200 \mathrm{ml}$ of milk.

This procedure was performed for each of the flavours evaluated as described by MiNIM (2010). Acceptance test of the samples was carried out by 121 panellists aged over 60, using cards with a hedonic scale of seven points. The study included elderly people who were participants of three different groups for third age in Viçosa, Minas Gerais. The test was performed in venues of such groups. 


\subsection{Statistical analysis}

To evaluate the protein quality, the data were submitted to analysis of variance (ANOVA) and means were tested by $t$-test.

For acceptance testing the data were evaluated initially by ANOVA and than by Tukey's test, and samples (flavours) and panellists as source of variation. Data from the acceptance test were submitted to Principal Component Analysis (PCA). The results were expressed in a dispersion graph of the samples (treatments) in relation the two first principal components and in other graph representing the loadings of the PCA (correlations between the data of each user with the first two principal components) (Minim, 2010). For data analysis the softwares Sigma Statisticâ for Windows (Fox et al., 1994) and Statistical Analysis Systems (SAS) version 9.0 were used, licensed by the Federal University of Viçosa. The level of statistical significance was $5 \%$.

\section{Results and discussion}

\subsection{Proximate composition}

The values found in the evaluation of the percentage composition of the supplement are presented in Table 2 .

Table 2. Centesimal composition of the food supplement

\begin{tabular}{lclc}
\hline Nutrients & $\begin{array}{c}\text { Average of triplicate } \\
(\mathrm{g} / 100 \mathrm{~g})\end{array}$ & Nutrients & $\begin{array}{c}\text { Average of triplicate } \\
(\mathrm{g} / 100 \mathrm{~g})\end{array}$ \\
\hline Moisture & 6.0 & Ash & 7.5 \\
Carbohydrates & 29.5 & Total fibre & 9.3 \\
Protein & 38.2 & Insoluble fibre & 5.8 \\
Lipids & 0.2 & Soluble fibre & 3.5 \\
\hline
\end{tabular}

Regarding energy, the chemical composition analysis revealed that the supplement has $351 \mathrm{~kJ}$ per serving (30 g), contributing for a total of $1055 \mathrm{~kJ}$ daily, when consumed three times a day. Therefore, elderly people in adequate nutritional status can consume the product with reduced number of servings, according to their needs, guided by a professional. For those in a state of malnutrition, one way to increase the calorific value would be to offer the product with skimmed milk instead of water, which would give an increase of $293 \mathrm{~kJ}$ per serving.

For carbohydrates, the intake of 50 to $60 \%$ of total energy (I.O.M., 2002) is recommended. For the supplement studied, the amount of digestible carbohydrate found in $100 \mathrm{~g}$ was 29.5 $\mathrm{g}$, representing $42.5 \%$ of the total energy of the product. Inulin, polydextrose, maltodextrin, and fructose were used to supplement the sources of carbohydrate. Saccharin was added as a sweetener. These elements contributed only relatively low calories and glycemic index to the supplement, and so that can be consumed by diabetic elderly people as well. VASQUES and co-workers (2007), studying women with mean age of $25.5 \pm 1.3$ years and body mass index of $20.3 \pm 0.7 \mathrm{~kg} \mathrm{~m}^{-2}$, found that the same food supplement evaluated in this study, has a low glycemic index. 
The fibres, as well as vitamins and minerals, are functional nutrients that enhance the nutritional benefits to the health of the elderly. The fibres presented in the supplement were analysed as total and insoluble fibres. The amount of dietary fibre found in $100 \mathrm{~g}$ of product was $9.3 \mathrm{~g}$, same as in plant foods, such as dried plum $(9.25 \mathrm{~g})$, oats (10.0 g), and fresh coconut $(9.4 \mathrm{~g})$, which are considered excellent food sources of fibre (PHILIPPI, 2002). According to RoBINSON and LEIF (2001), the recommendations for fibre in the elderly range from 20 to $35 \mathrm{~g} /$ day, and the fibre-rich foods, such as grains, fruit, and vegetables, are the main dietary sources. Therefore, a portion of the supplement would contribute to $11.2 \%$ of the recommendations, considering the recommendation of $25 \mathrm{~g}$ /day for fibres.

The supplement contains inulin, a prebiotic, which is a type of fibre that has physical properties that make it applicable in various food products, such as absence of colour and odour, stability at neutral $\mathrm{pH}$ and at elevated temperatures $\left(140{ }^{\circ} \mathrm{C}\right)$, as well as solubility higher than that of sucrose (PASSOS \& PARK, 2003). The amount of soluble fibre found in the product was $3.5 \mathrm{~g}$ per $100 \mathrm{~g}$ or $1.05 \mathrm{~g}$ per serving, adding $20 \mathrm{~kJ}$ to the total energy of the supplement, since each gram of fibre provides $6 \mathrm{~kJ}$ (NINESS, 1999).

The protein presented in the composition of the supplement came from animal source, representing a total of $38.2 \%$. It was in the form of albumin, collagen, milk powder, and concentrated whey protein. The source of the albumin is dehydrated egg white and collagen was obtained from the hydrolysis of animal products (beef and pork). The supplement contained vitamins: A, C, D, E, H, K, B2, B5, B6, B12, folate, and niacin plus the following minerals: calcium, iron, magnesium, zinc, iodine, phosphorus, selenium, chromium, and manganese.

The U.S. and Canadian recommendation (DRI) for men and women aged 51 to 70 years and above 71 years is $0.8 \mathrm{~g}$ protein $\mathrm{kg}$ /day, equivalent to $56 \mathrm{~g}$ /day for men and $46 \mathrm{~g}$ /day for women (I.O.M., 2002). The supplement provides, in 3 servings during the day ( $90 \mathrm{~g}), 35 \mathrm{~g}$ of protein, equivalent to $62.5 \%$ of the recommendation for men and $76 \%$ recommended by the DRI for women.

The amount of lipid was fixed at $0.2 \mathrm{~g}$, a low value compared to the other nutrients. The product was developed with the purpose of assisting the elderly with nutritional deficiencies and also those with chronic non-communicable diseases, such as hypercholesterolemia, cardiovascular disease, and diabetes, prevalence of which is high in this age group.

\subsection{Biological assay}

Analysing the protein nutritive value of the supplement, both PER and NPR of the product was significantly higher $(\mathrm{P}<0.05)$ than the standard protein casein, being highly effective in promoting growth and maintenance of body tissues. Calculating the relative PER and NPR, the food supplement was $111.69 \%$ and $100.79 \%$ in relation to the control group (Table 3).

Table 3. Feed efficiency ratio (FER), absolute protein efficiency ratio (PER), relative protein efficiency ratio (RPER), absolute net protein ratio (NPR), and relative net protein ratio (RNPR)

\begin{tabular}{lccccc}
\hline Treatment & FER & PER & RPER (\%) & NPR & RNPR (\%) \\
\hline CAS & $30.47 \pm 1.94 \mathrm{a}$ & $3.21 \pm 0.20 \mathrm{a}$ & 100 & $4.19 \pm 0.15 \mathrm{a}$ & 100 \\
SA & $35.42 \pm 3.08 \mathrm{~b}$ & $3.59 \pm 0.31 \mathrm{~b}$ & 111.69 & $4.64 \pm 0.31 \mathrm{~b}$ & 100.79 \\
\hline
\end{tabular}

Means followed by different letters in the column are statistically different by Tukey's test at 5\% probability. Diets: CAS: control diet of casein; SA: food supplement diet 
FRIEDMAN (1996) considers proteins high nutritional value that present PER values above 2.0. Thus, the protein from the supplement was considered to be of great nutritional value. This suggests that the protein used in the product can be a good food source for the maintenance and restoration of muscle mass in older adults, particularly those with malnutrition.

Table 4 presents data from in vivo True Digestibility. The supplement presented digestibility above $90 \%$. However, this value was lower than casein value $(\mathrm{P}<0.05)$.

Table 4. True digestibility (TD) and Relative true digestibility (DIGR)

\begin{tabular}{lcc}
\hline Treatment & Digestibility & Relative Digestibility (\%) \\
\hline CAS & $94.76 \pm 1.15 \mathrm{~b}$ & 100 \\
SA & $92.34 \pm 1.71 \mathrm{a}$ & 97.44 \\
\hline
\end{tabular}

Means followed by different letters in the column are statistically different by Tukey's test at $5 \%$ probability. Diets: CAS: control diet of casein; SA: food supplement diet

Digestibility is a measure of the percentage of proteins that are hydrolyzed by digestive enzymes and absorbed in the form of amino acids or any other nitrogen compound by the body. When certain peptide bonds are not hydrolyzed in the digestive process, part of the protein is excreted in faeces or processed into products of metabolism by microorganisms in the large intestine (SGARBIERI, 1987).

Although SA presented lower digestibility $(\mathrm{P}<0.05)$ than casein, their amino acids are absorbed and used for protein synthesis, as evidenced in the PER and NPR. The lower digestibility may have been influenced by the fermentation of the intestinal flora due to the higher fibre content in the test diet (SA), which results in increased excretion of microbial nitrogen. In healthy people, the effect of fibre was evaluated, with inulin and sugar beet as digestible nutrients in the diet (CASTiglia-Delavaud et al., 1998). Both sources decreased between $1-2 \%$ the digestibility of protein nitrogen, lipid and energy diet. The groups receiving fibre showed higher values of the number of defecations and faecal weight, attributed to the increased hydration of faecal mass and excretion of microbial mass.

\subsection{Sensory results}

Analysing the panellists, $87.18 \%$ of subjects were female and $12.82 \%$ were male. The average age, followed by the standard deviation, was $68.28 \pm 5.78$ years.

The results for the acceptance test of the supplement tested, obtained by analysis of variance, presented mean judgments between 5 and 6 (7-point scale), being between the hedonic terms "liked" and "liked very much". This score indicated that samples of banana, vanilla, and strawberry flavour are good alternatives to market for their quality of trade, i.e., acceptance and added nutritional value for the group to whom it is destined.

With the data obtained in the acceptance test of the four samples of supplement the analysis of the Internal Preference Mapping was performed (Figs 1 and 2).

The first principal component (PC) explained $46.37 \%$ and the second explained $28.00 \%$. Regarding the acceptance, the first two principal components explained the most part of the variance $(74.37 \%$ ) between the samples, and thus being sufficient to discriminate the samples. 


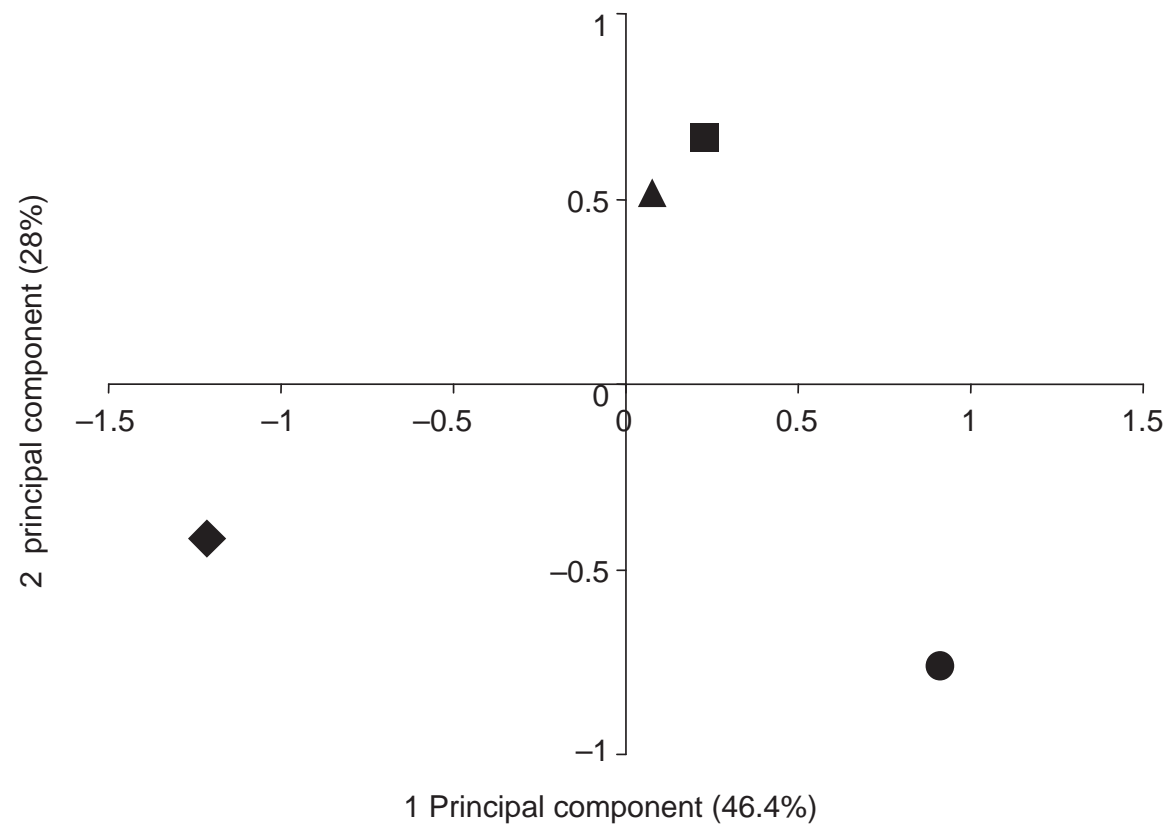

Fig. 1. Dispersion of supplement samples for the acceptance by the panellists : strawberry; $\boldsymbol{\Delta}$ : vanilla; $\mathbf{O}$ : banana; $\boldsymbol{\nabla}$ : chocholate

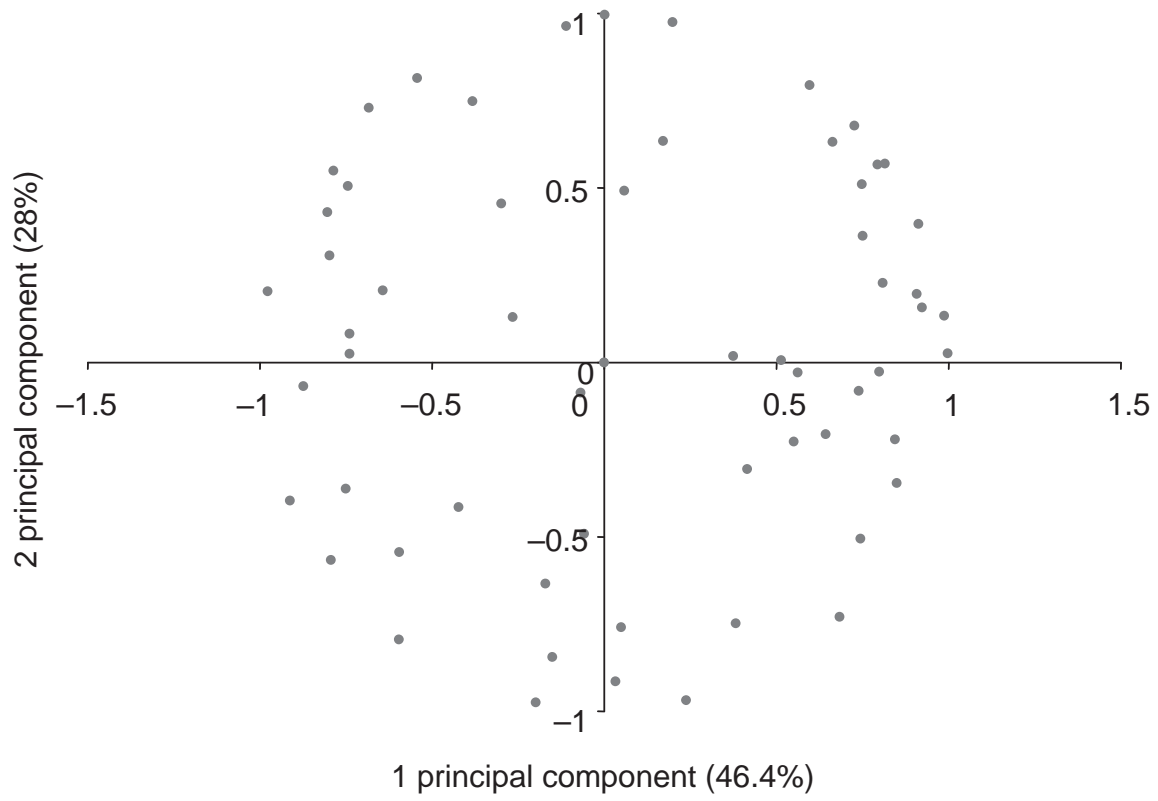

Fig. 2. Correlations between the data of acceptance of each panellist and the two principal components

The spatial separation of samples from the flavours of the supplement suggests the existence of three groups according to their acceptance, one group composed of vanilla and 
strawberry flavour (group 1), one of banana flavour (group 2), and one of chocolate flavour (group 3) (Fig. 1).

In Fig. 2 each point represents the correlations between the data of acceptance of a panellist and the first two principal components. The panellists correlated with at least one of the components consider a difference in the acceptance between the samples. Group 1 was accepted by a larger number of consumers and the chocolate flavour (group 3) was accepted by a smaller number of consumers.

The difference found in the acceptance test can be justified by physiological, nutritional, environmental, and socio-cultural characteristics. However, the sensory qualities of food are critical to food preference, and taste is the most important factor in the choice of food (GARCiA-BAilo et al., 2009).

During the sensory analysis, many of the panellists reported that the samples tested were "not sweet", which influenced the acceptance. However, this feature is desirable in this type of product, since this is directed toward the elderly, including those with abnormalities in glucose metabolism, such as the presence of insulin resistance or diabetes mellitus. It is noteworthy that in this study, all samples were accepted, according to the scale adopted.

The elderly are in risk group for lack of macro- and micronutrients, because maintaining adequate intake through a balanced diet often presents difficulties for them. Moreover, the foods consumed are low in calories, contributing to nutritional deficiency and malnutrition. Oral supplementation is effective and viable, and it is being used to provide an adequate nutritional surveillance, especially when this age group presents problems of malnutrition (SOUSA \& GUARIENTO, 2009).

\section{Conclusion}

The dietary supplement has an adequate nutritional composition, so it can partly cover the nutritional needs of the elderly regarding protein, fibre, vitamins, and minerals. The test results indicated that the biological product has good quality protein with PER and NPR values higher than casein, and digestibility above $90 \%$.

According to the results of sensory evaluation, the product had a good acceptance, making it a viable option to be sold, and to meet an increasing demand of products aimed at improving the nutrition of people aged 60 years or more.

The authors would like to thank the businessman B. Figueira Ramos, for giving samples of the supplement, used in this study, and the National Council for Scientific and Technological Development (CNPq).

List of abbreviations: PER: protein efficiency ratio; NPR: net protein ratio; FER: food efficiency ratio; TD: true digestibility; RDI: recommended daily intake; DRI: dietary reference intakes; NF: nitrogen-free diet; CAS: casein diet, SA: test diet; PCA: principal component analysis

\section{References}

A.O.A.C. (2002): Official methods of analysis, Moisture (method 934.01), dietary fiber content (method 991.43), total ash content (method 942.05), total protein content (method 984.13), total lipid (method 920.39). 16 ${ }^{\text {th }}$ ed., Washinghton, DC.

Bender, A.E. \& Doell, B.H. (1957): Note on the determination of net protein utilization by carcass analysis. $B r . J$. Nutr., 11, 138-143. 
Brazil Ministério da Saúde (Ministry of Health) (1998): Portaria SVS nº 32 de 13 de janeiro de 1998. Regulamento técnico para fixação de identidade e qualidade de suplementos vitamínicos elou de minerais. (Technical regulation for the determination of identity and quality of vitamin and/or mineral supplements.) Available at: $<\mathrm{http}$ // www.anvisa.gov.br>. Accessed June 10, 2009.

Castiglia-Delavaud, C., Verdier, E., Besle, J.M., Vernet, J., Boirie, Y., Beaufrere, B., De Baynast, R. \& Vermorel, M. (1998): Net energy value of no-starch polysaccharide isolates (sugar beet fibre and commercial inulin) and their impact on nutrient digestive utilization in healthy human subjects. Br. J. Nutr., 80, 343-352.

Fox, E., Kuo, J., Tilling, L.\& Ulrich, C. (1994): User's manual - Sigma stat: statistical software for windows. Jandel, Germany.

Friedman, M. (1996): Nutritional value of proteins from different food sources. A review. J. Agric. Fd Chem., 44, 6-29.

Garcia-Bailo, B., Toguri, C., Eny, K.M.\&El-Sohemy, A. (2009): Genetic variation in taste and its influence on food selection. J. Integrative Biol., 13, 69-80.

I.O.M. InstituTE OF Medicine (1997): DRI - Dietary reference intakes for calcium, phosphorus, magnesium, vitamin $D$, and fluoride. National Academy Press, Washington (DC). Available at: http.//www.nap.edu. Accessed Aug. 27, 2008.

I.O.M. Institute of Medicine (1998): DRI - Dietary reference intakes for thiamin, riboflavin, niacin, vitamin B6, folate, vitamin B12, pantothenic acid, biotin, and choline. National Academy Press, Washington (DC). Available at: http.//www.nap.edu. Accessed Aug. 27, 2008.

I.O.M. Institute of Medicine (2000): DRI - Dietary reference intakes for vitamin C, vitamin E, selenium and carotenoids. National Academy Press, Washington (DC). Available at: http.//www.nap.edu. Accessed Aug. 27, 2008.

I.O.M. Institute of Medicine (2001): DRI - Dietary reference intakes for vitamin A, vitamin K, arsenic, boron, chromium, copper, iodine, iron, manganese, molybdenum, nickel, silicon, vanadium, and zinc. National Academy Press, Washington (DC). Available at: http.//www.nap.edu. Accessed Aug. 27, 2008.

I.O.M. Institute of Medicine. Energy (2002): In: Dietary reference intakes for energy, carbohydrate, fiber, fat, fatty acids, cholesterol, protein, and amino acids. Washington (DC): National Academy Press; Part 1, 5.1-5.114.

Lima-Costa, M. \& Camarero, A. (2008): Demografia e epidemiologia do envelhecimento no Brasil (Demography and epidemiology of aging in Brazil). -in: Moraes, E.N. Princípios básicos de geriatria e gerontologia (Basic principles of geriatrics and gerontology). Coopmed, Belo Horizonte, Brazil, pp. 3-19.

Menezes, T.N.\&Marucci, M.F.N. (2005): Antropometria de idosos residentes em instituições geriátricas. (Anthropometry of elderly living in geriatric institutions.) Rev. Saúde Pública, 39, 169-175.

Menezes, T.N., Marucci, M.F.N.\&HolandA, I.M.M. (2005): Ingestão de cálcio e ferro alimentar por idosos residentes em instituições geriátricas de Fortaleza, CE. (Intake of calcium and iron food for elderly living in geriatric institutions of Fortaleza, CE.) Revista de Saúde Comunitária, 1, 100-109.

Minim, V.P.R (ED). (2010): Análise sensorial: estudos com consumidores. (Sensory analysis: consumer studies.) Editora UFV, Viçosa, 308 pages.

Niness, K.R. (1999): Inulin and oligofructose: what are they? J. Nutrition, 129, 1402-1406.

Otero, U.B., Rozenfeld, S. \& Gadelha, A.J. (2001): Óbitos por desnutrição em idosos, São Paulo e Rio de Janeiro. Análise de séries temporais. (Deaths due to malnutrition in the elderly, São Paulo and Rio de Janeiro. Time series analysis.) 1980-1996. Rev. Bras. Epidemiol., 4, 191-205.

PAssos, M.L.P. \& PARK, Y.K. (2003): Frutooligossacarídeos: implicações na saúde humana e utilização em alimentos. (Fructooligosaccharides: implications for human health and food production.) Ciência Rural, 33, 385-390.

Philippi, S.T. (2002): Tabela de composição de alimentos: suporte para decisão nutricional (Table of food composition: nutritional support for decision.) Coronário, São Paulo (SP), 107 pages.

Robinson, G.E.\&LeIf, B.J. (2001): Nutrition management\& restorative dining for older adults - practical interventions for caregivers. American Dietetic Association, Chicago, 395 pages.

SGARBieri, V.C. (1987): Métodos de avaliação da qualidade nutricional dos alimentos. (Methods for evaluating the nutritional quality of food.) -in: SGARBIERI, V.C. Alimentação e nutrição - fator de saúde e desenvolvimento (Food and nutrition - health and development factor). Almed, São Paulo, pp. 250-261.

Sousa, V.M.C. \& Guariento, M.E. (2009): Avaliação do idoso desnutrido. (Evaluation of malnourished elderly.) Rev. Bras. Clin. Med., 7, 46-49.

Treptow, R.O., Queiroz, M.I.\&Antunes, P.L. (1998): Preferência e aceitação de fatias desidratadas de maçãs (Malus domestica Borkh.) (Preference and acceptance of dried slices of apples (Malus domestica Borkh.).) Revista Brasileira de Agrociência, 4, 41-46.

Vasques, A.C.J., Sakon, P.O., Sant'anna, M.S.L.S., Carvalho, G.Q., Geraldo, J.M., Fabrini, S.P. \& Alfenas, R.C.G. (2007): Impacto do consumo de amendoim (Arachis hypogaea L.) no índice glicêmico de um suplemento alimentar protéico. (Impact of consumption of peanuts (Arachis hypogaea L.) in the glycemic index of a food supplement protein.) Nutrire, 32, 185. 